\title{
Metazoan Parasites of Geophagus proximus, a Cichlidae Fish from the Eastern Amazon (Brazil)
}

\author{
Marcos Sidney Brito Oliveira1*, Lincoln Lima Corrêa1, Liliane de Araújo Castro1, \\ Letícia Silva Brito ${ }^{1}$, Marcos Tavares-Dias ${ }^{2}$ \\ ${ }^{1}$ Universidade Federal do Oeste do Pará-UFOPA, Instituto de Ciências e Tecnologia das Águas (ICTA), Santarém, Brazil \\ ${ }^{2}$ Embrapa Amapá, Macapá, Brazil \\ Email: ${ }^{\star}$ marcosidney2012@hotmail.com
}

How to cite this paper: Oliveira, M.S.B., Corrêa, L.L., de Araújo Castro, L., Brito, L.S. and Tavares-Dias, M. (2017) Metazoan Parasites of Geophagus proximus, a Cichlidae Fish from the Eastern Amazon (Brazil). Natural Resources, 8, 268-277.

https://doi.org/10.4236/nr.2017.83015

Received: February 26, 2017

Accepted: March 28, 2017

Published: March 31, 2017

Copyright () 2017 by authors and Scientific Research Publishing Inc. This work is licensed under the Creative Commons Attribution International License (CC BY 4.0).

http://creativecommons.org/licenses/by/4.0/

\begin{abstract}
The present study investigated the fauna of metazoan parasites of a Geophagus proximus population from the lower Tapajós River, in the state of Pará, northern Brazil. A total of 137 monogeneans were collected from the gills of G. proximus, including Sciadicleithrum kritskyi, Sciadicleithrum paranaensis and Sciadicleithrum geophagi, while 119 Raphidascaris (Sprentascaris) lanfrediae nematodes and 28 metacercariaes of digenea undetermined were collected from the intestine. Hosts harboring four species of parasites were predominant. The parasites had an aggregated dispersion pattern. The present study represents the first record of $S$. geophagi parasitizing G. proximus, increasing the geographic distribution of these parasite species to the Tapajós River basin.
\end{abstract}

\section{Keywords}

Helminths, Parasites, Freshwater Fish, Tapajós River

\section{Introduction}

The Cichlidae Bonaparte, 1840 family comprises the greatest wealth of fish species, with 202 genera and around 1762 species [1]. Cichlids are freshwater fish, but some species can tolerate variations in salinity and may invade brackish water [1]. The family is widely geographically distributed and contains species with different life habits, with the majority of neotropical species presenting extragenital sexual dimorphism, wide variations in size and shape, diversified coloration and great potential for use in aquariums [1]. 
Among cichlid species, Geophagus proximus Castelnau, 1855 is endemic to South America, and is distributed in the Ucayali River in Peru and the Solimões-Amazon River, Tocantins River and the Trombetas River in Brazil [2]. This benthopelagic fish inhabits riverbanks and lakes, feeding on small fruits, seeds, algae, crustaceans, insect larvae and mollusks [3] [4]. Its sexual maturation occurs when it reaches approximately $12 \mathrm{~cm}$ in length, and it exhibits split spawning and the habits of incubating the eggs in the mouth and caring for its offspring after hatching [3].

Despite the wide geographical distribution of G. proximus and its importance for fishing, there are few studies on its parasitic fauna. [5] described the occurrence of Argulus chicomendesi Malta and Varella, 2000, Ergasilus turucuyus Malta and Varella, 1996, and Excorallana berbicensis Boone, 1919 in G. proximus from the Araguari River, in state of Amapá, Brazil. However, most studies with $G$. proximus have been carried out in regions where the fish does not occur naturally. For G. proximus from the Paraná River basin, in the state of Paraná (Brazil), Proteocephalidea, Austrodiplostomum compactum Lutz, 1928, Clinostomum heluans Braun, 1899, Clinostomum Leidy, 1856, Raphidascaris (Sprentascaris) hypostomi Petter and Cassone, 1984, Raphidascaris Railliet and Henry, 1915 and Contracaecum Railliet and Henry, 1912 [6] have been registered. For this host from the Ilha Solteira Reservoir, on the Dourados River, in state of São Paulo (Brazil), [7] described Sciadicleithrum kritskyi Bellay, Takemoto, Yamada and Pavanelli, 2009 and Sciadicleithrum paranaensis Bellay, Takemoto, Yamada and Pavanelli, 2009. Austrodiplostomum compactum was also reported in G. proximus from the Nova Avanhandava Reservoir, on the Tietê River, also in the state of São Paulo, Brazil [8].

Knowledge of parasitic infracommunities and their relationships with host fish is of great importance, as parasites play a key role in ecosystems, regulating the abundance and density of natural populations, therefore stabilizing food chains and host community structure [5] [9] [10] [11]. The present study therefore aimed to investigate the parasitic fauna of metazoans from $G$. proximus from Lake Juá in the Tapajós River basin, in the state of Pará, Brazil.

\section{Materials and Methods}

In September 2015, 23 specimens of G. proximus were collected in the Juá Lake located on the lower Tapajós River $\left(2^{\circ} 26^{\prime} 05.8^{\prime \prime S} 54^{\circ} 46^{\prime} 26.9^{\prime \prime} \mathrm{W}\right)$, in the municipality of Santarém, state of Pará, in the eastern Amazon region of Brazil (Figure 1). Gill nets were used to capture the fish (20 and $30 \mathrm{~mm}$ of mesh). All the fish were then transported alive to Multiple Production Laboratory for Aquatic Organisms (LAMPOA) of the West Pará Federal University (UFOPA), for parasitological analysis. The identification of $G$. proximus was through the morphological characteristics [12]. The study was carried out in accordance with the principles adopted by the Brazilian College of Animal Experimentation (COBEA). All the fish were collected pursuant to a collection authorization granted by IBAMA/ICMBio-N ${ }^{\circ}$ 46202-2/2015. 


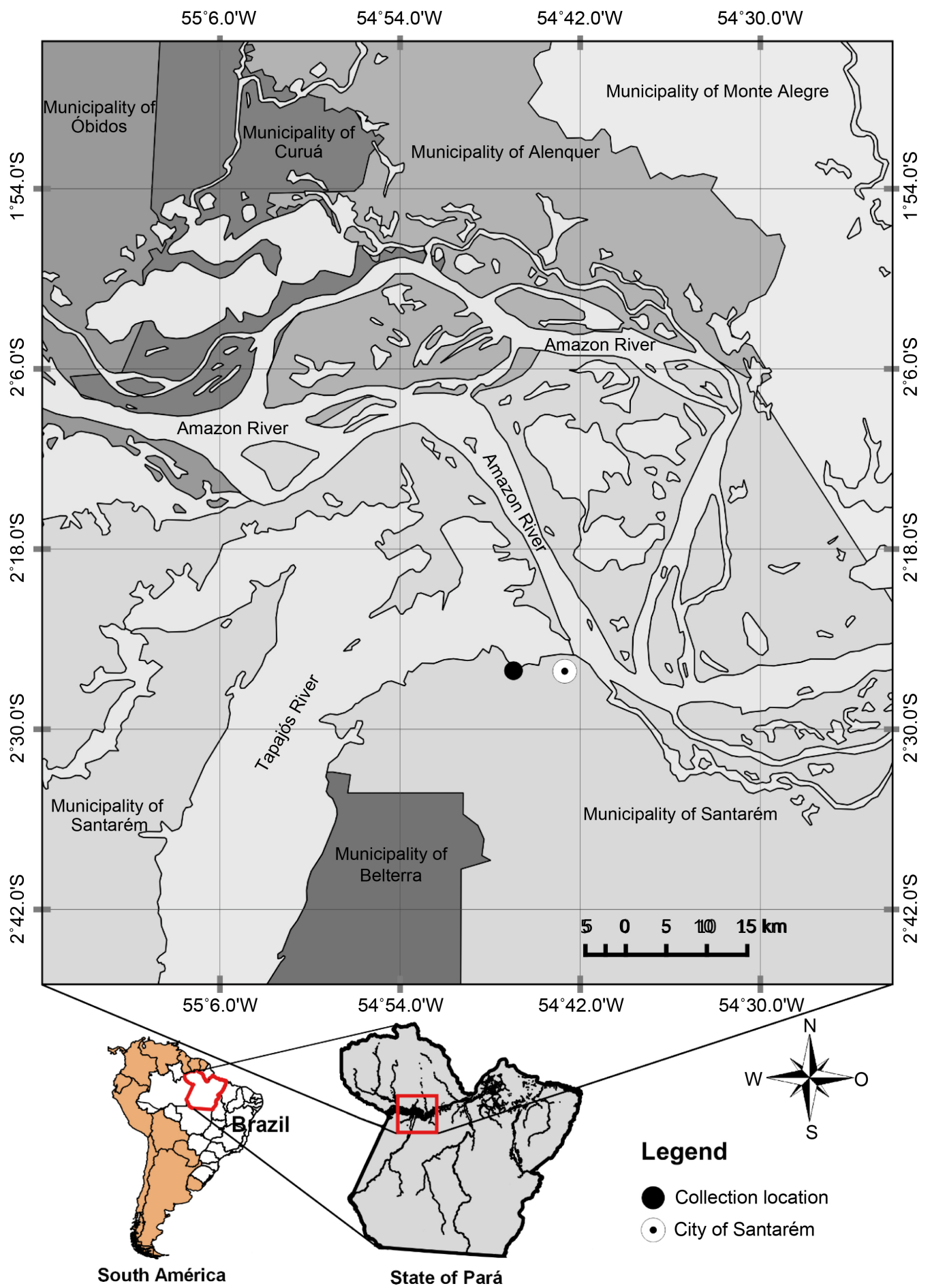

Figure 1. Collection sites of Geophagus proximus in the lower Tapajós River, state of Pará, in Eastern Amazon (Brazil).

After collection, each fish was euthanized by the spinal cord transection method, and the standard length $(\mathrm{cm})$ and total weight $(\mathrm{g})$ were measured. Then the mouth, gills, operculum and fins of each fish were examined to verify the presence of ectoparasites, and the viscera and gastrointestinal tract were analyzed for the presence of endoparasites. The collection, fixation and preparation 
of the parasites for identification followed the recommendations of [13]. The identification of the parasites was in accordance with [6] and [14], following the morphological characteristics.

The ecological terms used (prevalence, mean intensity, mean abundance) were those recommended by [15] and dominance frequency was evaluated in accordance with [16]. The degree of dispersion of each parasitic infra-community with prevalence $>10 \%$ was evaluated using the Green index, as shown by the equation:

$$
G I=\frac{\left(\frac{s^{2}}{\bar{x}}\right)-1}{n-1}=\frac{I C}{n-1}
$$

where: $G I=$ Green's index, $s^{2}=$ variance, $\bar{x}=$ mean number of individuals, $n=$ total number of individuals.

The dispersion index was tested using the $d$-statistic test, where $d>1.96=\mathrm{ag}$ gregate distribution; $d<-1.96=$ uniform distribution; $-1.96<d<1.96=$ random distribution [17].

\section{Results}

A total of 23 specimens of $G$. proximus measuring $\bar{x}=11.4 \mathrm{~cm} \pm 1.5 \mathrm{~cm}$ and $\bar{x}$ $=21.0 \mathrm{~g} \pm 8.5 \mathrm{~g}$ were analyzed, of which $95.7 \%$ were parasitized by one or more metazoan species, with the dominance of monogenoidean species. The species of parasites found were Sciadicleithrum kritskyi Bellay, Takemoto, Yamada and Pavanelli 2009; Sciadicleithrum paranaensis Bellay, Takemoto, Yamda and Pavanelli 2009; Sciadicleithrum geophagi Kritsky, Thatcher and Boeger, 1989 (Dactylogyridae); Raphidascaris (Sprentascaris) lanfrediae Melo, Santos, Giese, Santos and Santos 2011 (Raphidascarididae) and Digenea gen. sp. metacercariae (Trematoda) (Table 1).

The species richness of the parasites varied from 0 to 5 , although hosts infected by four species predominated (Figure 2). The parasites had an aggregated distribution pattern (Table 2).

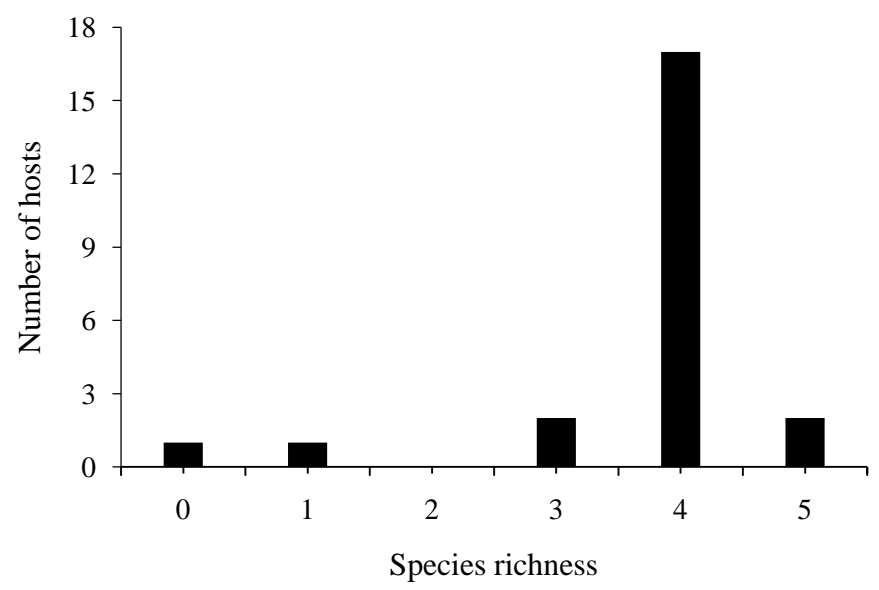

Figure 2. Species richness of metazoan parasites of Geophagus proximus from the lower Tapajós River, state of Pará, in Eastern Amazon (Brazil). 
Table 1. Metazoan parasites of Geophagus proximus from the lower Tapajós River, state of Pará, in Eastern Amazon (Brazil). P: Prevalence, MI: Mean intensity, MA: Mean abundance, TNP: Total number of parasites, IS: Infection sites, FD: Frequency of dominance.

\begin{tabular}{ccccccc}
\hline Parasite species & P (\%) & MI & MA & TNP & FD (\%) & IS \\
\hline $\begin{array}{c}\text { Monogenea } \\
\text { Sciadicleithrum kritskyi }\end{array}$ & & & & & & \\
$\begin{array}{c}\text { Sciadicleithrum paranaensis } \\
\text { Sciadicleithrum geophagi }\end{array}$ & 91.3 & $73.9 \pm 6.7$ & 6.0 & 137 & 0.482 & Gills \\
Nematoda & & & & & & \\
$\begin{array}{c}\text { Raphidascaris (Sprentascaris) lanfrediae } \\
\text { (larvae) }\end{array}$ & 73.9 & $7.0 \pm 4.6$ & 5.2 & 119 & 0.419 & Intestine \\
Trematoda & & & & & & \\
Digenea gen. sp. (metacercariae) & 21.7 & $5.6 \pm 3.1$ & 1.2 & 28 & 0.099 & Intestine \\
\hline
\end{tabular}

Table 2. Dispersion index (D), $d$-statistical test, Green index (G) for the infracommunities of metazoan parasites of Geophagus proximus from the lower Tapajós River, state of Pará, Eastern Amazon (Brazil).

\begin{tabular}{cccc}
\hline Parasites & D & $d$ & G \\
\hline Monogenea & 7.97 & 12.17 & 0.32 \\
Raphidascaris (Sprentascaris) lanfrediae & 4.21 & 7.05 & 0.15 \\
Digenea gen. sp. & 8.51 & 12.79 & 0.34 \\
\hline
\end{tabular}

\section{Discussion}

Different fish species are important hosts for the biological cycle of a variety of endoparasites, due to their behavior and feeding habits, which are important factors in the composition of their endoparasite fauna [9] [10] [18]. In the present study of $G$. proximus, while a total of five species of parasites were found, of which three were monogenoidea, one was nematoda and one was digenea, ectoparasites predominated. The species richness of parasites in G. proximus was similar to that of the same host from the Paraná River basin, in state of Paraná, Brazil [7]. On the other hand, it was less rich than that of Geophagus brasiliensis Quoy and Gaimard, 1824 from the Guandu River, in state of Rio de Janeiro, which presented fauna composed of 14 species of parasites [18], none of which occurred in the present study. Such differences are expected for congeneric species and those from different environments.

Aggregate distribution is a common pattern in freshwater fish parasites [19] and has been observed in other species of freshwater fish in Brazil [10] [18] [20] [21] [22]. This pattern of parasitic distribution may be influenced by the width of the ecological niche, environmental heterogeneity, and immunological and behavioral differences between individual hosts [2] [10] [22] [23] [24] as well as indicating little competition between parasites of the same species, which are allowed to occur in great abundance in the same host and at the same infection site. 
Monogeneans S. kritskyi, S. paranaensis and S. geophagi predominated in the G. proximus of the present study, indicating a greater contact with the infecting forms (oncomiracidium) of these monoxide parasites, which explained this predominance. In contrast, there was a low richness of endoparasite larvae such as $R$. (S.) lanfrediae and non-identified digenea, indicating that the diet of $G$. proximus diversified little in the environment studied, and was limited to a few items such as crustaceans and mollusks. In contrast, a greater richness of endoparasites was identified in $G$. proximus from the Paraná River, with the dominance of $A$. compactum [7]. For $G$. brasiliensis from the Guandu River, the dominance of Posthodiplostomum macrocotyle Dubois, 1937 [9] and Posthodiplostomum sp. [25] have been described.

Monogeneans $S$. kritskyi and $S$. paranaensis were originally described from $G$. proximus from the Paraná River basin, Brazil [6], where G. proximus was introduced. As such, we can assume that these parasites were transferred together with this host to this region of Brazil. According to [26] parasites transferred to regions where they do not occur naturally may specialize and parasitize other species of fish, competing with the natural parasites of this region. So far, however, there is no record of $S$. kritskyi or $S$. paranaensis parasitizing other species of fish. On the other hand, $S$. geophagi, originally described from the gills of Geophagus surinamensis Bloch, 1791 from the Negro River, in the state of Amazonas, Brazil [27], was first recorded here in G. proximus, and Lake Juá, in the Tapajós River basin in the state of Pará, is a new locality for this parasite. Sciadicleithrum geophagi has also been reported infecting other cichlids in the state of Amapá, such as Chaetobranchopsis orbicularis Steindachner, 1875 [11] and Geophagus camopiensis Pellegrin, 1903 [18].

Larvae of $R$. (S.) lanfrediae were found in the intestine of G. proximus with high prevalence, but low intensity and average abundance values. However, these levels of parasitism were higher than those recorded from Satanoperca jurupari Heckel, 1840 from the Guamá River. In general, Raphidascaris spp. uses Chironomidae species as primary intermediate hosts and small fish as intermediate hosts, reaching the adult stage in predatory fish [28]. Therefore, the fact that G. proximus is a small cichlid favors its predation. Raphidascaris $(S$.) lanfrediae is a nematode that has also been reported parasitizing Geophagus argyrosticus Kullander, 1991 and G. proximus from the Araguari River, in state of Amapá, and the Xingu River, in state of Pará [29], as well as $S$. jurupari from the River Guamá [14]. However, species of Raphidascaris have been reported parasitizing fish from the Loricaridae [30] [31], Pimelodidae [31] and Serrasalmidae [32] [33] families. This study extends the distribution of $R$. (S.) lanfrediae to the Juá Lake, in the western part of the state of Pará, Brazil.

Digenea are widely geographically distributed, and in South America are known 662 species infecting diverse fish species [34], as they parasite different species of vertebrates, especially fish and piscivorous birds. The life cycle of these endohelminths usually includes three hosts: mollusks, fish and piscivorous birds [35] [36]. Digenean metacercariae occurred in the intestine of G. proximus with 
low levels of infection, indicating that this host feeds on small mollusks in the studied environment. Depending on the region of Brazil, G. proximus has been infected by $A$. compactum [6] [8] and C. heluans [6]. However, the species of digenea in G. proximus from the Amazon are unknown.

\section{Conclusion}

In conclusion, the parasite community in G. proximus was composed by ectoand endoparasites, with low species richness and moderate infection levels. Geophagus proximus is an intermediate host for digeneans and $R$. ( $S$.) lanfrediae. Finally, more studies with parasites of natural populations of $G$. proximus from different localities of Brazil are suggested, to better understand the parasitic ecology of these host fish.

\section{Acknowledgements}

The authors would like to thank the Coordenação de Aperfeiçoamento de Pessoal de Nível Superior (the Coordination for the Improvement of Higher Education Personnel) (Capes) for the Master's grant awarded to M. S. B. Oliveira, and to the Conselho Nacional de Desenvolvimento Científico (National Council for Scientific Development) (CNPq) for the productivity scholarship awarded to M. Tavares-Dias.

\section{References}

[1] Nelson, J.S., Grande, T.C. and Wilson, M.V.H. (2016) Fishes of the World. 5th Edition, John Wiley and Sons, Hoboken. https://doi.org/10.1002/9781119174844

[2] Kullander, S.O. (2003) Family Cichlidae (Cichlids). In: Reis, R.E., Kullander, S.O. and Ferraris Jr., C.J., Eds., Check List of the Freshwater Fishes of South and Central America, Edipucrs, Porto Alegre, 606-654.

[3] Santos, G.M.S., Mérona, B., Juras, A.A. and Jégu, M. (2004) Peixe do Baixo Rio Tocantins: 20 Anos Depois da Usina Hidrelétrica Tucuruí. Eletronorte, Brasília, 216.

[4] Santos, G.M., Ferreira, E.J.G. and Zuanon, J.A.S. (2006) Peixes Comerciais de Manaus. Ibama/AM, PróVárzea, Manaus, 144.

[5] Vasconcelos, H.C.G. and Tavares-Dias, M. (2016) Host-Parasite Interaction between Crustaceans of Six Fish Species from the Brazilian Amazon. Acta Scientiarum. Biological Sciences, 38, 113-123.

https://doi.org/10.4025/actascibiolsci.v38i1.29601

[6] Bellay, S., Takemoto, R.M., Yamada, F.H. and Pavanelli, G.C. (2009) Two New Species of Sciadicleithrum (Monogenea: Dactylogyridae), Gill Parasites of Geophagus proximus (Castelnau) (Teleostei: Cichlidae), from the Upper Paraná River FloodPlain, Brazil. Zootaxa, 2081, 57-66.

[7] Zago, A.C., Franceschini, L., Zocoller-Seno, M.C., Veríssimo-Silveira, R., Maia, A. A.D., Ikefuti, C.V. and Da Silva, R.J. (2013) The Helminth Community of Geophagus proximus (Perciformes: Cichlidae) from a Tributary of the Paraná River, Ilha Solteira Reservoir, São Paulo State, Brazil. Journal of Helminthology, 87, 203-211. https://doi.org/10.1017/S0022149X12000223

[8] Zica, É.D.O.P., Wunderlich, A.C., Ramos, I.P. and Da Silva, R.J. (2010) Austrodiplostomum compactum (Lutz, 1928) (Digenea, Diplostomidae) Infecting Geophagus proximus Castelnau, 1855 (Cichlidae, Perciformes) in the Tietê River, Nova Avan- 
handava Reservoir, Municipality of Buritama, São Paulo State, Brazil. Neotropical Helminthology, 4, 9-15.

[9] Azevedo, R.K., Abdallah, V.D. and Luque, J.L. (2006) Ecologia da Comunidade de Metazoários Parasitos do Acará Geophagus brasiliensis (Quoy e Gaimard, 1824) (Perciformes: Cichlidae) do Rio Guandu, Estado do Rio de Janeiro, Brasil. Acta Scientiarum. Biological Sciences, 28, 403-411.

[10] Tavares-Dias, M., Neves, L.R., Pinheiro, D.A., Oliveira, M.S.B. and Marinho, R.G.B. (2013) Parasites in Curimata cyprinoides (Characiformes: Curimatidae) from Eastern Amazon, Brazil. Acta Scientiarum. Biological Sciences, 35, 595-601. https://doi.org/10.4025/actascibiolsci.v35i4.19649

[11] Bittencourt, L.S., Pinheiro, D.A., Cárdenas, M.Q., Fernandes, B.M. and TavaresDias, M. (2014) Parasites of Native Cichlidae Populations and Invasive Oreochromis niloticus (Linnaeus, 1758) in Tributary of Amazonas River (Brazil). Revista Brasileira de Parasitologia Veterinária, 23, 44-54. https://doi.org/10.1590/S1984-29612014006

[12] Kullander, S.O. (1986) Cichlid Fishes of the Amazon River Drainage of Peru. Swedish Museum of Natural History, 431.

[13] Eiras, J.C., Takemoto, R.M. and Pavanelli, G.C. (2006) Métodos de Estudo e Técnicas Laboratoriais em Parasitologia de Peixes. Ed. EDUEM, Maringá.

[14] Melo, M.D.F.C.D., Santos, J.N.D., Giese, E.G., Santos, E.G.N.D. and Santos, C.P. (2011) Raphidascaris (Sprentascaris) lanfrediae sp. nov. (Nematoda: Anisakidae) from the Fish Satanoperca jurupari (Osteichthyes: Cichlidae). Memórias do Instituto Oswaldo Cruz, 106 553-556. https://doi.org/10.1590/S0074-02762011000500006

[15] Bush, A.O., Lafferty, K.D., Lotz, J.M. and Shostak, W. (1997) Parasitology Meets Ecology on Its Own Terms: Margolis et al. Revisited. Journal of Parasitology, 83, 575-583. https://doi.org/10.2307/3284227

[16] Rohde, K., Hayward, C. and Heap, M. (1995) Aspects of the Ecology of Metazoan Ectoparasites of Marine Fishes. International Journal for Parasitology, 25, 945-970.

[17] Ludwig, J.A. and Reynolds, J.F. (1988) Statistical Ecology: A Primer on Methods and Computing. Wiley-Interscience Pub., New York.

[18] Ferreira-Sobrinho, A. and Tavares-Dias, M. (2016) A Study on Monogenean Parasites from the Gills of Some Cichlids (Pisces: Cichlidae) from the Brazilian Amazon. Revista Mexicana de Biodiversidad, 87, 1002-1009. https://doi.org/10.1016/j.rmb.2016.06.010

[19] Morrill, A. and Forbes, M.R. (2012) Random Parasite Encounters Coupled with Condition-Linked Immunity of Hosts Generate Parasite Aggregation. International Journal for Parasitology, 42, 701-706.

[20] Gonçalves, R.A., Oliveira, M.S.B., Neves, L.R. and Tavares-Dias, M. (2016) Seasonal Pattern in Parasite Infracommunities of Hoplerythrinus unitaeniatus and Hoplias malabaricus (Actinopterygii: Erythrinidae) from the Brazilian Amazon. Acta Parasitologica, 61, 119-129. https://doi.org/10.1515/ap-2016-0016

[21] Oliveira, M.S.B., Gonçalves, R.A. and Tavares-Dias, M. (2016) Community of Parasites in Triportheus curtus and Triportheus angulatus (Characidae) from a Tributary of the Amazon River System (Brazil). Studies on Neotropical Fauna and Environment, 51, 29-36. https://doi.org/10.1080/01650521.2016.1150095

[22] Oliveira, M.S.B. and Tavares-Dias, M. (2016) Communities of Parasite Metazoans in Piaractus brachypomus (Pisces, Serrasalmidae) in the Lower Amazon River (Brazil). Revista Brasileira de Parasitologia Veterinária, 25, 151-157. 
https://doi.org/10.1590/S1984-29612016022

[23] Anderson, R.M. and Gordon, D.M. (1982) Processes Influencing the Distribution of Parasite Numbers within Host Populations with Special Emphasis on ParasiteInduced Host Mortalities. Parasitology, 85, 373-398. https://doi.org/10.1017/S0031182000055347

[24] Shaw, D.J. and Dobson, A.P. (1995) Patterns of Macroparasite Abundance and Aggregation in Wildlife Populations: A Quantitative Review. Parasitology, 111, S111S133. https://doi.org/10.1017/s0031182000075855

[25] Carvalho, A.R., Tavares, L.E. and Luque, J.L. (2010) Variação sazonal dos metazoários parasitos de Geophagus brasiliensis (Perciformes: Cichlidae) no Rio Guandu, Estado do Rio de Janeiro, Brasil. Acta Scientiarum. Biological Sciences, 32, 159 167.

[26] Lacerda, A.C.F., Yamada, F.H., Antonucci, A.M. and Tavares-Dias, M. (2013) Peixes introduzidos e seus parasitos. In: Pavanelli, G.C., Takemoto, R.M. and Eiras, J.C., Eds., Parasitologia de peixes de agua doce do Brasil, Eduem, Mringá, 169-193.

[27] Kritsky, D.C., Thatcher, V.E. and Boeger, W.A. (1989) Neotropical Monogenea. 15. Dactylogyrids from the Gills of Brazilian Cichlidae with Proposal of Sciadicleithrum gen. n. (Dactylogyridae). Proceedings of the Helminthological Society of Washington, 56, 128-140.

[28] Moravec, F. (1970) Studies on the Development of Raphidascaris acus (Bloch, 1779) (Nematoda: Heterocheilidae). Vestnik Ceskoslovenske Spolecnosti Zoologicke, 34, 33-49.

[29] Pereira, F.B. and Luque, J.L. (2017). An Integrated Phylogenetic Analysis on Ascaridoid Nematodes (Anisakidae, Raphidascarididae), Including Further Description and Intraspecific Variations of Raphidascaris (Sprentascaris) lanfrediae in Freshwater Fishes from Brazil. Parasitology International, 66, 898-904. https://doi.org/10.1016/j.parint.2016.10.012

[30] Moravec, F., Kohn, A. and Fernandes, B.M.M. (1990) First Record of Raphidascaris (Sprentascaris) hypostomi (Petter et Cassone, 1984) comb. N. and r. (s.) Mahnerti (Petter et Cassone, 1984) comb. N. (Nematoda: Anisakidae) from Brazil with Remarks on the Taxonomic Status of the Genus Sprentascaris Petter et Cassone, 1984. Folia Parasitologica, 37, 131-140.

[31] Kohn, A., Moravec, F., Cohen, S.C., Canzi, C., Takemoto, R.M. and Fernandes, B. M. (2011) Helminths of Freshwater Fishes in the Reservoir of the Hydroelectric Power Station of Itaipu, Paraná, Brazil. Check List, 7, 681-690. https://doi.org/10.15560/7.5.681

[32] Moreira, A.L.H., Yamada, F.H., Ceschini, T.L., Takemoto, R.M. and Pavanelli, G.C. (2009) The Influence of Parasitism on the Relative Condition Factor (Kn) of $\mathrm{Me}$ tynnis lippincottianus (Characidae) from Two Aquatic Environments: The Upper Parana River Floodplain and Corvo and Guairacá Rivers, Brazil. Acta Scientiarum. Biological Sciences, 32, 83-86.

[33] Yamada, F.H., de Aquino Moreira, L.H., Ceschini, T.L., Lizama, M.D.L.A.P., Takemoto, R.M. and Pavanelli, G.C. (2012) Parasitism Associated with Length and Gonadal Maturity Stage of the Freshwater Fish Metynnis lippincottianus (Characidae). Neotropical Helminthology, 6, 247-253.

[34] Luque, J.L., Pereira, F.B., Alves, P.V., Oliva, M.E. and Timi, J.T. (2016) Helminth Parasites of South American Fishes: Current Status and Characterization as a Model for Studies of Biodiversity. Journal of Helminthology, 18, 1-15.

[35] Brasil-Sato, M.C. and Santos, M.D. (2003) Helmintos de Myleus micans (lütken, 
1875) (Characiformes: Serrasalminae) do rio São Francisco, Brasil. Revista Brasileira de Parasitologia Veterinária, 12, 131-134.

[36] Bullard, S.A. and Overstreet, R.M. (2008) Digeneans as Enemies of Fishes. Fish Diseases, 2, 817-976.

Submit or recommend next manuscript to SCIRP and we will provide best service for you:

Accepting pre-submission inquiries through Email, Facebook, LinkedIn, Twitter, etc. A wide selection of journals (inclusive of 9 subjects, more than 200 journals) Providing 24-hour high-quality service User-friendly online submission system Fair and swift peer-review system Efficient typesetting and proofreading procedure Display of the result of downloads and visits, as well as the number of cited articles Maximum dissemination of your research work

Submit your manuscript at: http://papersubmission.scirp.org/ Or contact nr@scirp.org 